\title{
Analysis on Development and Economic Effect of Green Building
}

\author{
Changzhi Wu \\ Sias International University \\ Zhengzhou, China
}

\begin{abstract}
This article explores and analyzes the significance of green building design and states new concept of green building design. In order to establish the concept to realize sustainable development of green building, this article introduces the concept and characteristics of green building, states the meaning of green building development from many aspects and puts forward the strategy to develop green building economy and green building materials. Modern civilization brings people the convenience and comfort. Meanwhile, we also gradually realize the isolation brought by buildings for human and nature and its damage and influence on the environment. In order to let buildings back to nature and close to nature to realize coexistence of buildings and nature, experts and scholars put forward the concept of "green building". Green buildings refer to buildings to provide people with comfortable, healthy and safe living space, make use of resources with high efficiency in life cycle of buildings and minimally influence the environment. It is also called ecological building and sustainable building.
\end{abstract}

Keywords—green building; economy; strategy

\section{INTRODUCTION}

Modern science and technology brings people fun. Meanwhile, we are aware of the influence and damage brought by modern building for human and nature. In order to make buildings return to nature and realize the coexistence between buildings and nature, building circles put forward the concept of "green building". Green buildings provide comfortable, healthy and safe space for people to work and live in. At the same time, in the whole life cycle of buildings, it makes use of resources with high efficiency and minimally influences the environment. It is also called ecological building and sustainable building.

The economic construction in our country grows rapidly. In every year, the area of newly-built buildings is about three billion square meters. The construction investment with enormous scale reaches up to several trillion yuan. But in the process of construction and use, it directly consumes 30 percent of total energy consumption of the whole society, 47 percent of municipal water, 30 percent of steel quantity of our country and about 25 percent of cement. In face of the development situation of construction industry, it has a farreaching influence to save land, resources and water and realize the sustainable development concept of environmental protection.
It is in urgent need of developing green buildings to adjust structure of real estate industry and change growth pattern of construction industry and promote the adjustment of economic structure. It is the inevitable requirement to promote comprehensive utilization of resources, build conservationminded society and develop circular economy; it is the key link to save resources and guarantee national energy security; it is the basic solution to explore and solve the problems of high investment, high consumption, high pollution and low efficiency in construction industry; it is the major strategic task to transform traditional construction industry and building materials industry and realize healthy, coordinated and sustainable development of construction cause.

\section{BASIC CONNOTATION OF GREEN BUILDING}

The "green" in the so-called green building doesn't refer to vertical planting or roof garden, but represents a kind of concept or symbol. It refers to buildings that are harmless to the environment, can make full use of natural resources in the environment and don't damage the basic ecological balance of the environment. It can be called buildings with sustainable development, ecological buildings, buildings back to nature, energy-saving and environmentally friendly buildings.

The basic connotation of green buildings can be summarized as: reduce the load of buildings on the environment, namely save energy and resources; provide safe, healthy and comfortable living space; be close to natural environment, realize harmonious coexistence of human, buildings and the environment and sustainable development. Modern green buildings are not limited to buildings that we can see. It also includes building materials and building pattern. Green buildings also have relationship with elevator, such as OTIS elevator. OTIS aims at providing the safest and the most reliable scheme for clients to take the elevator. As the world's leading supplier to provide elevators, escalators and moving walk, it always pursues the development concept of energy conservation and environment protection, continuously promote the technical innovation in the field of energy conservation and environmental protection, brings the advanced technology of energy conservation and environmental protection that keeps pace with the world in China, in order to better serve the construction of conservation-minded society and sustainable development in China. The technology that "elevators can produce energy" researched and developed by OTIS first can change potential 
energy and kinetic energy in running process of elevators into electric energy, and couple it back to the power grid, to provide electricity for other electric equipment in the building, which greatly save electricity utilization and make outstanding contributions for green buildings.

\section{DEVELOPMENT OF GREEN BUILDING DESIGN}

Green buildings can provide more comfortable environment. It depends on the property of buildings. It includes ontology of architecture, internal and external environmental ecological system of the buildings. Through overall design, green buildings integrate innovative and high technologies such as green configuration, natural ventilation, lighting, low-energy space enclosing structure, new energy utilization, reuse of recycled water, green building materials and intelligent control and have the characteristics of reasonable location planning, high efficient circulation of resource utilization, comprehensive and effective energy conservation measures, healthy and comfortable built environment, reduction and harmlessness of waste emissions, flexible and proper building function. Indoor environment decides comfort level of people. Green buildings can make full use of resources, improve indoor comfort level in buildings through various reasonable green technologies, guarantee healthy life of people and provide good living and environment quality for residents. On problem of economic externality, the market cannot assure to reach effective allocation of resources. A certain degree of government interference can realize effective allocation of resources. The economic incentive policies of green buildings are to use this principle to promote the development of green buildings. Strengthen the guidance of concepts to save lands, energies, materials and publicity and education, deepen the understanding of all sectors of society for importance of green buildings. Colleges shall improve construction of relevant disciplines related to green buildings, cultivate all kinds of professional and technical personnel required by development of green buildings, and strengthen continuing education of compound talents on green buildings through multiple channels to improve the ability of vocation personnel to apply green buildings. Our country is in transformation period of market economy. Green buildings shall follow rules of market economy. Establish demonstration projects to guide the market, define policy orientation, eliminate market risks, attract investment on green buildings and create good external environment and market conditions. It is necessary to consider economic efficiency when paying attention to advancement of green buildings. At present, there are few information indexes in our country and inadequate quantitative analysis. It shall not lag behind on concept. There are too many deficiencies in projects on project management and technology implementation. The market of green buildings is chaotic and has fierce competition. The construction management of green buildings is decided by multiple factors. Units such as system integrator, building unit and property management companies have influences on construction quality of green buildings. Low price tender reduces systematic construction quality of green buildings. Green buildings can measure and calculate initial price and operational consumption of architectural elements, closely connect professional experts with users, adjust relations between departments, subdivide responsibilities and let projects get scientific and effective management.

\section{NEW OPPORTUNITIES AND CHALLENGES FACED BY GREEN BUILDING ECONOMY}

When construction industry transforms to "green building", building economy faces new opportunities and challenges. When making decisions on moving towards green, owners consider interior effects as well as return of total investment. So for investors, green buildings are economic responsibility as well as social responsibility. "Effective use of resources" is the advantage of green construction technology, to reduce utilization of building materials, various resources and nonrenewable energy resources; make use of renewable energy and materials, set waste recycling system and reuse old materials if the structure allows. Reduce emissions of pollutants and furthest decrease damages to surrounding environment. Green construction is also the buildings that integrate comfort, health and safety, protect the environment and are close to nature. The promotion of "green construction" needs to realize effectively using energies and resources and having minimum influences on the environment in the whole life cycle of buildings. In production process of construction products, "building construction" is an important link. It refers to the production process that building enterprise organizations base on requirements of design documents, use machines and tools and materials to construct "buildings" on drawings through technological process. Keeping ecological environment and saving energies are substantive objectives of "green construction". Strictly optimize and implement construction technologies and schemes of engineering project. Ensure the construction process "saves energy, land, water, material and protects the environment". "Green construction" is not the quality required by traditional construction, or passively adapts to traditional construction technology, but makes overall planning on the whole process of technology improvement of traditional construction, under the premise of ensuring quality and safety, realizes the maximization of environmental protection effect in construction process. Although the cost of green construction is high, it has lower energy consumption and influence on the environment. The life cycle cost is firstly put forward by United States Department of Defense. The operation and support costs of typical weapon system account for 75 percent of purchase cost of products. Research conducted by National Institute of Standards and Technology shows that the life cycle cost includes initial cost and future cost. We think that the generalized full life cycle cost of construction project refers to all expenses produced by producer, consumer and the public in life cycle of construction project. The full life cycle cost of construction project includes cost of capital, environment cost and social cost. Green construction is an important period in whole life cycle of construction project. Although implementing green construction and optimizing the overall scheme increase relative cost of capital, it also reduces environmental cost and social cost. In other words, it reduces life cycle cost, which is more aligned with idea of social sustainable development. 


\section{DEVELOPMENT OF GREEN BUILDING MATERIALS}

For new type of building material industry in our country, the period from 1979 to 1998 is the important historical period for development of new type of building materials. Through 20 years of development, the new type of building material industry basically completes the development process. It forms burgeoning industry and new economic growth rate in our country. The promotion of new type of building materials is an important part of development of green materials and only needs the degree of promotion of green building materials to have qualitative changes. The promotion of green building materials is restricted by many aspects. Green buildings have inadequate public cognition, which become the barrier to promote green building materials; building materials industries mainly center on traditional construction materials; the true technology of green building materials isn't mature. With the participation of enterprises, the concept of "green buildings" will be further popularized. Green buildings are "updated version" of energy saving building. Compared with traditional buildings, the consumption of various resources and energies in green buildings will reduce about 30 percent. The follow-up maintenance cost reduces 30 percent to 50 percent. It saves about 20 percent of materials in water, electricity and heating. Except for environmental protection, the most impressive place is that it is comfortable and livable. Yantai has good foundation to let real estate upgrade to "green". Among national prefecture-level cities, Yantai is the first to vigorously implement integration of design and construction of solar energy and buildings. At present, the utility ratio of newlybuilt houses fewer than 12 layers (include 12 layers) reaches 100 percent, with 50 percent utility ratio of houses more than 12 layers. The area of buildings that integrate with solar energy is 12 million square meters. In 2012, Yantai City became the prefecture-level city that takes the lead in realizing full coverage of application demonstration of national renewable energy buildings.

On World Expo in Shanghai in 2010, green building materials are widely applied. The site selection of variety hall of World Expo is a monolayer factory building of steel bent frame. The length from east to west is 228.5 meters. The width from south to north is 92.8 meters. In the construction process, it firstly tears down the roof and then consolidates the original net rack with more than 1,000 square meters to form hollow meshy roof. Afterwards, build modern glass curtain wall in inner rock wool outside the building to reach the effects of thermal insulation and energy conservation. Irregular shape of red auditorium is built in glass lounge of polygon. It seems as though red diamonds sparkles in crystal box. They install new type of landscape lighting system, "light clouds", on net rack reserved on roof of variety hall. It will have "a riot of color" at night. Most of the heating and cooling inside the building are completed by three sets of gas appliances. This device is equipped with thermostatic valve with automatic adjustment according to the procedure. The heating of large meeting room that can contain many audiences is supplied by thermal radiation floor. The cooling is completed through the device that forces the circulation of air. The ventilation is carried out through using air condition and matched heat recovery unit. For the circulation of air, the adjustable diffuser under the floor lets fresh air enter most area of the new building. Part of the power supply in this building is provided by electro-optical system with $2.2 \mathrm{KW}$. The photoelectric solar panels are arranged on corridor, balcony and roof. Microclimate data acquisition station uses it to collect wind power and thermal data, in order to monitor solar energy collection of every day. The solar energy is used by power system in the building. The electrical power system will supplement when solar power is insufficient in rainy days. The power, communication and data systems are settled in flexible channel installed in the wall. The energy-saving type of floodlight adopts fluorescent lamp and electronic ballast. The lighting uses many devices with rotary knobs, in order to coordinate with daylight illumination. When the building isn't used completely, users can integrate working lighting system with natural lighting in small scopes.

The reduction plan is to control construction waste. For residential housing, the construction waste of each 10,000 square meters should not exceed 400 tons. Strengthen recycling and reusing of construction waste, make efforts to realize the recycling and recovery rate of construction waste can reach 30 percent. Besides, the recycling and recovery rate of waste produced by demolition of buildings is greater than 40 percent. For construction wastes such as broken stones and cubic meter of earth and stone, adopt the patterns of foundation landfill and paving to improve reuse rate, strive to make the reuse rate exceed 50 percent. In living quarters of construction site, set closed type of garbage container. Put household garbage in construction site in bags and timely collect them. Classify construction wastes and collect them to closed type of garbage station in construction site and cart them intensively.

\section{CONCLUSION}

Green buildings can meet the requirements of sustainable development and realize the unification of development and environment as well as modern and long term combination. It meets the requirements of modern people, makes them live and work in peace and contentment and have good health and a long life and doesn't damage greater requirements of future generations for environment and resources. In a word, the booming development and the process of greening of green building industry have relationship with the development of green building industry, problem about whether it can integrate with international green market, the improvement of national living quality, the sustainable development of national economy and the people's livelihood. Its contribution is in contemporary era, and it will benefit throughout the ages. Therefore, it is necessary to use strategic version, sense of urgency of the era and sense of historical responsibility to make efforts to promote sound development of green buildings and create healthy, safe, comfortable and beautiful buildings and indoor environment to benefit human society.

\section{REFERENCES}

[1] Dong Jibin. Green GDP and New Energy and Industrial Base Construction, on Economic Problems, 2005(1): 1-4.

[2] Zhu Yan, Niu Zhiping. Concept of Sustainability of Construction Project and Post Evaluation Research, Construction Economy, 2006(1): 5-10. 
[3] Zhang Chongren. Ways to Implement Green Construction [J], Building, 2005(7): 126-129

[4] Li Meiyun, Fan Canliang. Research on Assessment Indicator System of Green Construction, Engineering Construction, 2008(01): 56-60

[5] Liu Kecheng. Green Building System and Its Research, New Architecture, 1997(04): 8-10

[6] Development and Future of Contemporary Green Architecture, Construction Times. 